\title{
O FENÔMENO DA PARENTALIDADE DISTRAÍdA E ABANDONO AFETIVO: QUANTO CUSTA O CUIDADO NA SOCIEDADE TECNOLÓGICA
}

Resumo: O presente estudo visa despertar o debate para um exercício parental prejudicado ou deficiente em razão da distração causada pelo uso excessivo de celulares, computadores e aparelhos digitais. A convivência em pais e filhos é posta à prova de modo a questionar até onde cabe responsabilizações jurídicas frente a abandonos de cuidado em detrimento da opção por telas brilhantes. De modo dedutivo, pretender-se-á demonstrar a relação de causa e consequência apresentada em uma sociedade de risco pós-moderna, que transborda para o ambiente familiar e pode gerar uma nova espécie de demanda judiciária.

Palavras-chave: Parentalidade. Celulares. Filhos. Abandono Afetivo. Sociedade

\section{THE PHENOMENON OF DISTRICTED PARENTALITY AND AFFECTIVE ABANDONMENT: HOW MUCH DOES THE CARE COST IN THE TECHNOLOGICAL SOCIETY}

\begin{abstract}
The aim of this study is to stimulate the debate on a parental exercise impaired or deficient due to the distraction caused by the excessive use of cell phones, computers and digital devices. The coexistence in parents and children is put to the test in order to question how much legal responsibility is responsible for abandonment of care over the option of bright screens. In a deductive way, it will be tried to demonstrate the relation of cause and consequence presented in a society of postmodern risk, that overflows to the familiar environment and can generate a new species of judicial demand.
\end{abstract}

Keywords: Parenting. Cell phones. Children. Affective Abandonment. Society

\section{INTRODUÇÃO}

É cada vez mais notória a dinâmica e o perfil da sociedade contemporânea, na qual a interatividade, velocidade, efemeridade e intensidade compõem a conjuntura pós-moderna da

\footnotetext{
${ }^{1}$ Advogada em São Luís/MA, especialista em Direito do Consumidor pela Universidade CEUMA e pós-graduanda em Direito da Família, Infância e Juventude pelo Centro Universitário BOM BOSCO - UNDB. Email: leticiaprazeres@outlook.com.br
} 
comunidade global. Forma-se um panorama que parece representar uma via de mão dupla: ao mesmo passo em que se avança e se desfruta dos progressos alcançados, não se pode negar as peculiaridades negativas de cada inovação, afinal de contas o corpo social hodierno é fruto de uma sociedade de risco ${ }^{2}$ ora anunciada, na qual para cada conquista há uma perda seja no campo econômico, político, social, entre outros.

Seguindo este raciocínio, percebe-se a intensificação do uso dos meios tecnológicos por parte das famílias, sejam elas brasileiras ou não. Computadores, celulares, tablets e relógios digitais, por exemplo, passaram a ser instrumentos presentes em todos os momentos do convívio familiar, seja na esfera organizacional, de lazer ou a trabalho; certo é que o uso destes mecanismos passou a disputar o tempo de vivência e convivência dos membros destes núcleos.

Pesquisas recentes ${ }^{3}$ apontam que é cada vez mais comum o aumento por parte dos pais na utilização dessas tecnologias. Cabe dizer que não seria um uso esporádico ou considerado razoável, mas sim algo que acaba por comprometer a própria interação, educação e formação para com seus filhos. A problemática da discussão surge então justamente quando é indagado se em um cenário onde a parentalidade se demonstra um tanto quanto distraída, em decorrência de um exercício deficiente, seria possível falar de um abandono afetivo e suas demais consequências jurídicas.

Para que se faça viável a construção deste debate é interessante o enfoque no fenômeno da parentalidade distraída, enquanto consequência da influência pós-moderna na conformação atual dos seios familiares, de modo que tal apresentação forme o substrato para tratar a respeito da relação entre tal fenômeno e o abandono afetivo. Falar a respeito deste enlace é avaliar até que ponto há uma conexão entre ambos e de que modo causa e consequência factíveis viriam a instigar o mundo jurídico, tanto no sentido de conhecer os institutos em si, e avaliar seus pontos de impactos, como também no estabelecer de parâmetros de julgamento e responsabilização por eventuais danos.

\footnotetext{
${ }^{2}$ Com o avanço da indústria, ciência e tecnologia, observou-se um progresso que trazia consigo consequências maiores do que as previstas e nem sempre reparáveis. Embora a figura do meio ambiente e da saúde humana fossem as que de início poderiam sofrer tal impacto, de maneira indireta aspectos econômicos, políticos e sociais também eram levados por esta onda, na qual progredir nem sempre significa um efetivo crescimento e desenvolvimento (BECK,2018).

${ }^{3}$ Desperta-se para os riscos advindos do uso exacerbado pelos pais das tecnologias de informação, seja no tocante ao aspecto físico, moral ou psíquico, certo é que tal comportamento ultrapassa a barreira do aceitável e atinge aqueles sujeitos necessitados do dever de cuidado. Ao observar a presente constatação, pesquisadores da Universidade de Michigan e de Illinois (EUA), viram ser plausível e de extrema relevância tentar entender a correlação entre meios de comunicação e o exercício parental. (McDANIEL; RADESKY,2017).
} 
O método de abordagem será o dedutivo, visto que se parte de uma análise mais ampla que engloba os aspectos e características da sociedade pós-moderna e sua interferência nos conceitos de família contemporâneos, até um ponto mais especifico que seria o surgimento da parentalidade distraída e seu impacto em um possível abandono afetivo, vindo então a abrir espaço no tema da responsabilidade civil. No tocante à técnica de pesquisa (GIL, 1999), far-seá o uso de coleta documental, literária, doutrinária e de dados. Neste último, utilizar-se-á a modalidade de entrevista informal visto que, em razão do conteúdo abordado não ser ainda discutido de forma significativa no Brasil, procurou-se um profissional pioneiro para a aquisição do conhecimento.

\section{SOCIEDADE INFORMATIZADA E O EXERCÍCIO PARENTAL}

Qualquer que seja o tipo de evolução, pressupõe-se um ultrapassar de etapas até a chegada de um estado presente. Cada síntese histórica que é formada é fruto de uma dialeticidade de teses e antíteses que marcam um contrapor de ideias e modelos até o surgimento de algo fruto dessa discussão. Esse é o movimento natural da construção dos paradigmas sociais, que não obstante, acaba por ser também o movimento natural das sociedades em si, são frutos de somas e subtrações, multiplicações e divisões das mais diversas referências até o encontrar de resultados.

A comunidade pós-moderna faz parte de um progresso tridimensional no qual o mercado, a tecnologia e a individualidade são os alicerces de uma geração na qual a noção de evolução quebra conceitos, desfaz relações sólidas e questiona certas formas de condutas (LIPOVETSKY, 2004). Há um contraponto de ganhos e sacrifícios que a configuram por vezes, como o retroceder de avanços tão almejados, do mesmo modo que o uso da tecnologia é o responsável por colocar em xeque o que de fato se conquistou.

Aperfeiçoamentos ${ }^{4}$ que envolvem o uso de inteligências programadas e sistemas informacionais passaram a fazer parte das mais diversas formas de relação, utiliza-se a

\footnotetext{
${ }^{4}$ Elementos como a robótica, informática, rede mundial de computadores e transmissão de dados acabam por influenciar a forma de viver das sociedades atuais, seja no aspecto pessoal, como também no social e político. Por óbvio, nem sempre essa rede é íntegra o suficiente para aproximar, causando também rupturas, desigualdades e distorções que vão influenciar em desdobramentos futuros. Absolutamente tudo é ingerido pela velocidade da
} 
tecnologia no avanço científico, médico, econômico, nas maneiras de fazer política e ainda no tecer redes de troca de cultura, dados, mensagens e comunicações. É justamente neste ponto que surge uma das composições da sociedade contemporânea, a faceta informacional: a conhecida "Sociedade de Informação $5 "$ ". Uma vez possuindo como suporte básico o uso das ferramentas tecnológicas, este novo agrupamento se funda em uma verdadeira rede de ideias, instrumentos, conhecimentos e discursos que fazem da ideia de um campo totalmente abstrato, uma influente fonte de poder (SANTIAGO, 2012).

As consequências que as tecnologias de informação e comunicação trazem para as diversas populações são diferentes, pois cada sociedade recebe esses novos mecanismos de informação e comunicação de forma diferenciada, adaptando-os com os aspectos econômicos, sociais, culturais e históricos de cada nação (SANTIAGO, 2012, p. 38).

Por óbvio esse fluxo de dados recebe por meio dos instrumentos digitais como smartphones, relógios inteligentes, tablets e computadores uma espécie de materialização, a informação passa tanto a ser aquilo que ali está em destaque, como também o que é processado pelo receptor e o que é propagado em meio à dinâmica da emissão de conhecimento. Para além disto, aquisições de tais inovações passaram a ser entendidas enquanto recursos que podem gerar uma qualidade de vida, uma integralização no que diz respeito à sociabilidade ou a reafirmação da individualidade de cada sujeito pós-moderno (CARVALHO, 2008).

Seguindo este raciocínio, é perceptível que se tornou cada vez mais comum a colocação desses recursos nos lares das famílias mundiais, seja para facilitar a comunicação, auxiliar em trabalhos ou proporcionar o lazer; olhar em meio às telas se deu quase que na mesma proporção do interagir olhos nos olhos. Exatamente neste contexto, observou-se um uso exacerbado, uso este que não consiste em momento isolado ou quando há uma efetiva necessidade, passar a olhar e interagir de forma conectada se transfigurou como uma atividade primordial.

informação e dos dados, construindo assim um novo patamar coletivo, o de "sociedade de rede" (CARVALHO, 2008).

${ }^{5}$ Essa era do saber e do conhecimento cria uma nova sociedade onde a informática representa uma ferramenta que facilita a absorção de informações e contribui para transformar a estrutura do conhecimento e da realidade em que se vive. [...] a telefonia celular, as videoconferências, a TV a cabo, as transações bancárias online e a internet se tornam ferramentas usuais na comunicação entre cidadãos, no trabalho ou fora dele (ALMEIDA, 2006, p. 22) 
Celulares acompanham as pessoas nas mais diversas tarefas, ocupam a concretização de encontros que passam a ser via aplicativos de conversa e se tornaram vilões quando o assunto é estabelecer um diálogo sem nenhuma interferência midiática. Soa estranho pensar que a tecnologia progressista tanto estudada, investida e aplicada se tornou algo que prejudica, exclui e compromete as relações humanas. De todo modo, é bem factível constatar que a sociedade vigente, no que diz respeito ao uso em demasia de smartphones, é consequência de um contexto em que estar conectado passou a ser uma espécie de "camisa a ser vestida" pelo ser humano, a socialização virtual é sinônimo de inclusão e o acesso às ferramentas de informações é um mecanismo de garantia fundamental (DE MORAES, 2018).

Acontece que, diferentemente da atenção dada a crianças e adolescentes no tocante ao uso precoce e exacerbado desses aparelhos, percebeu-se que existiam membros das famílias que também necessitavam de uma cautela maior. A tecnologia de informação não mais se concentrava nas mãos de jovens e colocava em risco o correto desenvolvimento enquanto sujeitos em formação, mas se detectou a imersão exorbitante dos pais no mundo das telas brilhantes. Quem mais deveria saber dos riscos de uma midiatização em seio familiar também passou a ser acometido por um anseio em estar conectado, em estar informado e, assim, sentirse pertencente a algo.

O fato de possuírem uma maior idade ou um "maior" discernimento a respeito de possíveis riscos não impossibilita que adultos também mergulhem no mundo digital e troquem relações físicas e presentes por momentos no ambiente tecnológico (McDANIEL; RADESKY,2017). É o que se tem percebido frequentemente em relação aos pais e filhos, passou a ser cada vez mais comum que aqueles não consigam, não possam ou até mesmo não queiram dar a devida atenção aos jovens, o exercício de um poder parental passa a ser deficiente e um tanto quanto alheio frente ao dever-ser social, moral e constitucional.

Diante deste enfoque, passou-se a chamar de parentalidade distraída o exercício do poder parental prejudicado, deficiente e carente em decorrência do uso dos aparelhos de informática e digitais, em especial os celulares (McDANIEL; RADESKY,2017). A distração implica justamente em uma falta ou insatisfatória atenção, zelo, conversa, de modo que todo eixo e concentração do adulto é dirigida à ferramenta informacional. Pensa-se estar dando a 
devida dedicação àquela criança, quando na verdade os olhos e a atividade cerebral miram em um contexto completamente alheio à realidade.

É deste modo que o pediatra e educador Daniel Becker (2018) conceitua este novo fenômeno que vem se fazendo presente nos lares familiares brasileiros e mundiais. Segundo ele, há um baixo vínculo parental que desemboca em comportamentos de abandono e negligência para com crianças e adolescentes, é uma espécie de descuido que acontece dentro âmbito familiar. Enxerga-se um cuidar distraído por parte dos responsáveis: seja ao não observar corretamente uma criança e esta vir a se acidentar, em razão do responsável encontrarse olhando o celular, na ausência de vontade ou correto empenho no dialogar e estabelecer conversas com os filhos, em decorrência do interesse em aplicativos bate-papo e redes sociais, ou mesmo no atribuir aos smartphones uma espécie de terceirização do dever parental.

No mesmo passo, o educador também chama a atenção para o fato de que tal fenômeno possa ser mais presente dentro de famílias de classe alta na sociedade, e isto não é difícil de ser entendido na medida em que as mesmas possuem maior acesso na aquisição dessas tecnologias. Da mesma forma, se levar em consideração o ritmo de vida das grandes cidades e a desumanização dos grandes centros urbanos, observa-se uma espécie de prisão domiciliar, nos quais pais atribuem a celulares uma espécie de ambiente seguro e formador, no qual todos estão salvos e alheios de qualquer eventualidade que prejudique a figura da família. Não obstante, a distração informacional ocorre similarmente visto que proprietários de sites e redes nos quais os pais navegam, são empresas com forte interesse de lucro, e manter aqueles adultos no ambiente paralelo concretiza um possível interesse de compra ${ }^{6}$ futuro (BECKER, 2018).

Levando em consideração esse tipo de conduta na geração de pais pós-globalizados, percebeu-se ainda que havia uma correlação entre essa parentalidade distraída e comportamentos de rebeldia, agressividade, autoritários e tendentes à ansiedade e depressão por parte dos seus filhos. Tudo isso nada mais é do que a formação de uma espécie de estresse tóxico causado por esse abandono e esta negligência. Pais estão contribuindo para a formação de crianças e jovens carentes de princípios basilares para a construção de uma identidade individual e social, e que futuramente tendem a desencadear consequências biopsicossociais fruto de ações e omissões familiares (McDANIEL; RADESKY,2017).

\footnotetext{
${ }^{6}$ Embora tenha ocorrido uma facilitação nas maneiras de aquisição de bens e serviços ligados ao ambiente virtual, não se pode dizer que há uma democratização desses meios. Isto ocorre no sentido de que o adquirir por vezes, não diz respeito à uma necessidade fática e sim a um sentimento pós-moderno de inclusão e reconhecimento social (GIDDENS, 2001).
} 
Ao que parece, não adianta ter tanto avanço e ao mesmo passo retroceder tão significativamente em condutas necessárias para a convivência entre pais e filhos. Fica perceptível uma espécie de relação de causa e consequência da sociedade de risco pósglobalizada no momento em que se intensificam sinais, redes e cabos de fibra, e de um outro lado se fragilizam laços familiarmente edificados. Sacrifica-se o conviver coletivo em prol de uma vivência individualista, levantando então a percepção de que a família pós-moderna é muito mais do que um simples exemplo de instituição, passando a ser resultado dos fluxos e

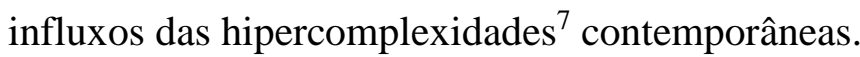

\section{A PARENTALIDE AUSENTE COMO QUEBRA DO DEVER DE CUIDADO}

Resta evidente que a parentalidade distraída é resultado de uma realidade sociológica das famílias vigentes onde a interrupção ou não existência de interação de pais e filhos acaba afastando, direta ou indiretamente, todos os sujeitos pertences àquele grupo. Nota-se um tipo de abandono em que indivíduos e máquinas disputam a atenção de pessoas que em tese deveriam estar aptas e dispostas a contribuir para a formação de uma criança ou adolescente.

A parentalidade distraída coloca em voga uma espécie de releitura do abandono familiar, abandono este que não significa um afastamento físico de pais e filhos, mas um espaço abstrato que marca tanto quanto uma separação fática. As figuras do afeto e do cuidado parecem um tanto quanto prejudicadas, visto que ser gentil e cuidadoso com seu filho, nos dias hodiernos, é presenteá-lo com um celular de última geração, por exemplo. Embora não pareça, a troca de momentos de diálogo por conversas em aplicativos de bate-papo, é também abrir mão da vivência familiar, é substituir o lazer propriamente dito por situações em que o uso de computadores e celulares ocupam a maior espaço do tempo livre dos adultos (LOMEU, 2010). Por óbvio, não se está defendendo que não deve haver nenhum tipo de ingerência tecnológica por partes dos pais em suas vidas, mas chama-se a atenção para a intensidade que o uso dessas ferramentas pode impactar em um deixar de lado sujeitos vulneráveis e de formação constante.

\footnotetext{
${ }^{7}$ Debates oriundos das reconfigurações das relações familiares frente à chegada e uso das tecnologias de informação (BASTOS, 2018).
} 
Fica perceptível que o exercício de um afeto parental resta deficiente e em alguns momentos até inexistente. Pais e filhos devem estabelecer laços de convivência acima de tudo, e não apenas uma mera vivência, devem compartilhar de conversas, cuidados, empatia, zelo e preocupações. Ora, perceber que a parentalidade distraída pode ocasionar uma forma de abandono afetivo é reconhecer a vulnerabilidade da sociedade progressista, é reconhecer que existem vínculos que não devem ser substituídos ou diminuídos em prol de uma atenção virtual.

O princípio da afetividade possui uma construção axiológica, uma espécie de compilado sistemático em que a ternura, a paixão, o afeto ${ }^{8}$, dedicação e atenção devem estar presentes e perpetuar as relações parentais. Embora não haja uma previsão expressa na Carta Magna, a afetividade surge com o enlace do Princípio da Proteção Integral à Criança e o da Dignidade da Pessoa Humana, reconhece-se que o afeto é primordial para o crescimento daquela criança enquanto cidadão e sujeito de direitos. O Direito de Família contemporâneo identifica no afeto o alicerce basilar para as relações e configurações familiares, é o que une, o que identifica, fortalece e nutre esse tipo de laço (LOMEU, 2010).

Dizer que um pai ou mãe não corrobora com um dever de cuidado, em prol do desfrute tecnológico, é dizer que aquele jovem não dispõe da devida atenção que deveria ter. É dizer que não há uma interação entre os sujeitos, a distração sobrepõe a comunicação e a dedicação, supera-se a ideia de conviver para a de apenas viver em família. Por óbvio, quando o Estatuto da Criança e do Adolescente em seu art. $3^{\circ}$ ou mesmo no art. 1638, II do Código Civil pressupõem garantias essenciais àquele considerado ser em formação e alerta para a perda do poder familiar, está sendo defendido que atos de abandono, e no caso o afetivo, são motores propulsores de impactos na esfera física, moral, espiritual e social daquele filho, há uma interrupção do dever de cuidado que deveria ser contínuo e fragilização de hábitos tão essencialmente necessários:

A rapidez e o excesso de informações, de ferramentas tecnológicas, aliados à rotina sobrecarregada, facilitam para que as relações entre as pessoas aconteçam com mais velocidade e com menos qualidade e compromisso de continuidade. Sendo os momentos de relações pessoais, incluindo conversas informais, abraços, confidências, relatos vividos no dia a dia, cada vez mais raros, é inevitável que, dentro de uma

\footnotetext{
8 A concepção de afeto enquanto elemento que caracteriza os grupos familiares é algo extremamente contemporâneo. As concepções e modelos de famílias que permearam momentos históricos se baseavam em uma relação pautada na obediência do patriarcado, na dinâmica industrial e formação de mão de obra, a figura da criança e do adolescente era menosprezada visto que eram tratados como pequenos adultos. O afeto pós-moderno surge para demonstrar que família não é algo singularizado em laços de sangue e sim no querer bem, na relação de solidariedade, cuidado e amor para com os demais integrantes (DIAS, 2005).
} 
mesma casa, pais 'desconheçam' gostos, pensamentos, amizades, interesses e ideias dos filhos e, também, o desenvolvimento escolar (GOULART; THOMAZINI, 2018, p.54/55)

Jovens que crescem em lares assim, possuem tendência a ser agressivos, rebeldes, desafiarem a autoridade de pessoas mais velhas, podem vier a praticar ou mesmo a sofrer bullying, podem ser acometidos de distúrbios alimentares e de ordem psicológica (McDANIEL; RADESKY,2017). São jovens que não possuem a devida atenção, orientação e ternura que deveria ser advinda dos pais, passam a procurar diálogos com terceiros, sentem a necessidade de suprir essa carência, sejam em um ambiente também virtual ou no uso de remédios, e assim acaba que se forma um ciclo vicioso em que a ausência de afeto pode gerar sujeitos vazios de princípios e inseguros quanto a sentimentos e relações subjetivas.

A própria ideia do coview e coplay ${ }^{9}$ serve para estimular as relações familiares, o estar junto, o fazer junto, jogar junto, olhar junto, coaduna para que sejam valorizados e dedicados momentos entre pais e filhos. As tecnologias de comunicação possibilitam sim programas, aplicativos e recursos em que aqueles possam manusear juntos, mas nada disso deve substituir o abdicar do mundo virtual para que haja a valorização da realidade afetuosa (BECKER, 2018).

Justamente por ter ocorrido uma reformulação do conceito de família, é mister salientar que a figura do afeto nasce para demonstrar que o que de fato vale é o dia a dia construído em conjunto, é a troca, é o balanço entre o silêncio para ouvir e a atenção voltada à conversa. Há de fato, uma construção doutrinária e até mesmo fática que traduz a afetividade enquanto algo que todo ser humano deveria ter e compartilhar para com o próximo. Por óbvio, não se defende uma obrigatoriedade de afeto entre familiares, mas sim uma presunção da sua relevância enquanto pilar útil e fundamental para o desenvolvimento de crianças e adolescentes em tempos tecnológicos (BASTOS; SOARES, 2015).

Falar de abandono afetivo oriundo de uma parentalidade distraída é alertar para condutas anunciadas na modernidade e que em meio à uma sociedade de informação pósmoderna, parecem ganhar força. As concepções de interatividade, efemeridade e intensidade oportunizam a reflexão de que nem sempre o viver unicamente no agora é suficiente para ter-

\footnotetext{
${ }^{9}$ A ideia de coview (olhar junto) e coplay (jogar junto) incentiva os momentos e as relações familiares não só frente à uma diversão oriunda da tecnologia, como também no resgate à brincadeiras e situações que precedem a era digital (BECKER, 2018).
} 
se uma qualidade de vida digna. Não é um computador que por si só irá formar o caráter de um indivíduo, não são jogos e aplicativos de mensagens que vão ajudar na formação acadêmica e profissional de uma criança, não são programas e redes sociais que vão determinar a posição de um adolescente no mercado, mas sim todo o alicerce moral e social que só a relação parental pode proporcionar. E se, quem deveria dispor dessa responsabilidade não a faz em decorrência de um anseio tecnológico, parte-se para o ponto que para aquele individuo apenas a conectividade virtual importa. Preceitos basilares são deixados de fora de modo a colaborar para gerações constitucionalmente e dignamente carentes.

\section{REPERCUSSÕES JURÍDICAS ENTRE A RESPONSABILIDADE CIVIL POR ABANDONO AFETIVO E PARENTALIDADE DISTRAÍDA}

A discussão que permeia o abandono afetivo e eventual responsabilidade não é nova, há um certo tempo já se debate até que ponto falar desse tipo de afastamento é também falar em responsabilização civil. A ideia de abandono, segundo LÔBO (2009), fere princípios como o da Solidariedade Familiar, Dignidade da Pessoa Humana, Responsabilidade ${ }^{10}$ e Proteção Integral à Criança, fere preceitos constitucionais e infraconstitucionais de modo a impactar para além de uma esfera privada daquele jovem.

Para quem defende um reconhecimento jurídico desse desamparo e coloca a figura da responsabilidade civil, há a constatação do abandono afetivo enquanto uma espécie de ato ilícito, que atinge honra, integridade física e psicológica de um indivíduo (art. 12 do Código Civil), ofende também a ampla noção do dever de educação por parte dos pais e responsáveis gerando assim algo que "compense” a rejeição praticada (TARTUCE, 2009).

Do mesmo sentido, coloca-se em destaque que a boa-fé deve estar presente nas condutas praticadas em seio familiar, muito mais do que uma espontânea dedicação, o que se preza é a correta consciência da relevância da tutela daquele pai para com seu dependente, o dever de cuidado deve sobrepor uma mera cautela patrimonial e sim valorizar elementos intrínsecos ao desenvolvimento e proteção de uma criança ou adolescente. Tribunais que vieram

\footnotetext{
${ }^{10}$ A Responsabilidade Parental não pode ser vista enquanto uma obrigação isolada, abarca diversas condutas que respondem por um bem-estar, cuidado e compromisso para com aquela criança ou adolescente. Exatamente neste sentido, que tratar de abandono afetivo frente à essa responsabilidade é demonstrar não só as consequências "extrajudiciais" que tal conduta pode levar, como também avaliar a medida desse inadimplemento frente aos deveres que circundam a posição de garantidor destes pais (LÔBO, 2009).
} 
a julgar em prol do reconhecimento do instituto do abandono afetivo e estabeleceram dano moral, viram nesse tipo de posição uma forma de indenizar algo que embora não se possa mensurar ${ }^{11}$, poderia ser minimizado. Problemas presentes e futuros, como o pagamento a apoio psicológico ou auxilio na formação escolar por exemplo estariam abarcados na imposição dessa conduta (BASTOS; SOARES, 2015).

Partindo disto, interessante faz-se pensar na possibilidade de uma eventual responsabilidade civil por abandono afetivo em razão da prática de parentalidade distraída. Embora não haja ainda no Brasil tal discussão, é possível traçar alguns pontos que merecem reflexão, afinal de contas o Direito é fruto de uma realidade sociológica e nada mais sensato do que este estar a par dos novos fenômenos que permeiam a coletividade e o Direito de Família, em especial.

Um primeiro quesito a ser levantado seria se a parentalidade distraída por si só poderia ser considerada ato ilícito (art. 186-187 do Código Civil), tendo vista o abandono. Inicialmente vislumbra-se a conduta humana de não dar atenção, não cuidar, orientar, aconselhar, conviver com o filho em decorrência do uso intenso e desproporcional de mídias tecnológicas. Quanto ao nexo causal é perfeitamente admissível, diante de estudos em desenvolvimento, que tal negligência afetiva por parte dos pais pós-globalizados pode gerar sim um abandono afetivo. A ação ou omissão oriunda de um descuido parental fruto da preferência virtual ou mesmo do

${ }^{11}$ CIVIL E PROCESSUAL CIVIL. FAMÍLIA. ABANDONO AFETIVO. COMPENSAÇÃO POR DANO

MORAL. POSSIBILIDADE. 1. Inexistem restrições legais à aplicação das regras concernentes à responsabilidade civil e o consequente dever de indenizar/compensar no Direito de Família. 2. O cuidado como valor jurídico objetivo está incorporado no ordenamento jurídico brasileiro não com essa expressão, mas com locuções e termos que manifestam suas diversas desinências, como se observa do art. 227 da CF/88. 3. Comprovar que a imposição legal de cuidar da prole foi descumprida implica em se reconhecer a ocorrência de ilicitude civil, sob a forma de omissão. Isso porque o non facere, que atinge um bem juridicamente tutelado, leia-se, o necessário dever de criação, educação e companhia - de cuidado - importa em vulneração da imposição legal, exsurgindo, daí, a possibilidade de se pleitear compensação por danos morais por abandono psicológico. 4. Apesar das inúmeras hipóteses que minimizam a possibilidade de pleno cuidado de um dos genitores em relação à sua prole, existe um núcleo mínimo de cuidados parentais que, para além do mero cumprimento da lei, garantam aos filhos, ao menos quanto à afetividade, condições para uma adequada formação psicológica e inserção social. 5. A caracterização do abandono afetivo, a existência de excludentes ou, ainda, fatores atenuantes - por demandarem revolvimento de matéria fática - não podem ser objeto de reavaliação na estreita via do recurso especial. 6 . A alteração do valor fixado a título de compensação por danos morais é possível, em recurso especial, nas hipóteses em que a quantia estipulada pelo Tribunal de origem revela-se irrisória ou exagerada. 7. Recurso especial parcialmente provido (Superior Tribunal de Justiça. Terceira Turma. REsp n ${ }^{\circ}$ 1159242/SP, Relatora Ministra Nancy Andrighi. Julgado em 24/04/2012, DJe 10/05/2012. 
lugar ao "viver em rede" em detrimento do correto dever de zelo, esclarece que há sim nexo entre esses dois fenômenos.

A perspectiva do dano também é possível de ser identificada visto que a desatenção parental pode contribuir para um fragilizar de laços e futuros desdobramentos nas esferas física, moral e social daquela criança ou adolescente. No tocante à culpa, também se faz pertinente tal relação já que aqui trata-se da culpa em sentido subjetivo, mais precisamente na culpa stricto sensu ao tratar de negligência. Ora parece ser verossímil reconhecer que a conduta da parentalidade distraída pode ser considerada um ilícito frente à ocorrência do abandono afetivo, devendo então ocorrer uma imputação ao dever de indenizar por eventuais danos morais ou mesmo materiais.

Todavia, embora haja uma relação de encaixe entre os quesitos ora expostos e a distração parental, não se pode esquecer que o que está sendo debatido é a figura do cuidado. Cuidado este que rege as relações familiares cotidianas e serve de identificador das mais diversas formas de arranjos familiares. O que se levanta diante disto, não seria a aproximação à correntes e posições que defendem o afeto ser algo imensurável e não passível de valor monetário, não seria dizer que a autonomia implica uma liberdade nas ações dos indivíduos em vida privada e que considerar uma intervenção estatal seria um abuso de poder por parte daqueles que regem a estabilidade e convívio social. Não, o que se chama a atenção é que o instituto da parentalidade distraída reflete um estilo de vida contemporâneo que tende a questionar o que de fato vale nos dias de hoje, até que medida o estar presente é responsável por um garantir e construção de um futuro.

Judicializar esse debate talvez não seja o melhor caminho, considerar a influência tecnológica enquanto responsável pelo desequilíbrio e desunir entre pais e filhos é afirmar que o progresso pode sim virar pauta, pode aumentar as demandas nos tribunais e quiçá desenvolver novas legislações. Seria considerar o avanço científico e informacional como novo condutor da vida social, e neste sentido desvirtuar toda a noção de humanidade que permeia um sujeito.

Por conta da sensibilidade presente na discussão da parentalidade distraída, o manejo dos meios alternativos de conflito pode ser uma opção para a resolução ou amenização dessa quebra entre pais e filhos, em especial a mediação. Mais do que retirar o foco da objetividade, formalidade e por vezes morosidade dos processos judiciais, a mediação traz consigo a ideia dos sujeitos participantes do conflito enquanto personagens ativos e diante disto, a perspectiva 
do encontrar de um denominador comum que ponha fim à situação de instabilidade e rompimento de laços.

O tratamento do abandono afetivo por uma eventual parentalidade distraída é algo delicado e deve ser tido enquanto um problema que transcende a esfera privada de uma família, é pensar que indiretamente pessoas podem são (re) criadas para a mecanização das relações em sociedade. Seria então através da mediação ${ }^{12}$ que poderia ser razoável falar no contextualizar, ouvir e no entender dos pontos de vista de cada sujeito de um núcleo familiar, no tocante ao uso exacerbado de tecnologias, e assim reestabelecer o canal antes tido enquanto interrompido (BASTOS; SOARES, 2015)

Um trabalho de educação preventiva desse tipo de comportamento parental também é uma opção para que haja uma espécie de conscientização dos responsáveis. Reuniões, atividades dentro de escolas, creches, centros comunitários, de assistência social ou ainda palestras em lugares de grande fluxo como shoppings, são pontos estratégicos de alcançar pais e filhos. Faz-se mister apontar que implantar e elaborar campanhas e trabalhos desse tipo, é realizar uma releitura, uma expansão do princípio da solidariedade familiar. Tal preceito não deve ser visto exclusivamente como algo devido por integrantes do núcleo familiar principal, mas sim de todos aqueles que colaboram direta ou indiretamente para essa formação. Uma sociedade preocupada em enriquecer esses laços, é uma sociedade que se preocupa com a formação de novas gerações e a garantia do conhecimento e cumprimento de direitos fundamentais (SAMPAIO, 2009).

O Estatuto da Criança e Adolescente (Lei no 8.069/1990) respalda toda a dinâmica dos direitos destes para com os deveres daqueles que devem zelar por todas as suas formas de integridade, do mesmo modo que coloca o Estado e sociedade enquanto também garantidores.

O dever de colaboração tríade posta é outra faceta da solidariedade enquanto princípio que deve reger a família. Ora, falar de ajuda mútua e intenções somadas em prol de um único objetivo é fazer jus à essência dos direitos fundamentais de terceira geração, nos quais a

\footnotetext{
${ }^{12}$ Por isso, é preciso incorporar as mudanças de comunicação operadas pela tecnologia nos núcleos familiares com qualidade. Para tanto, a mediação, com seu procedimento, técnicas, ferramentas e bases socio-filosóficas, pode auxiliar de forma efetiva e construtiva nessa incorporação, além de favorecer a construção de entendimentos autônomos e personalizados para os conflitos provenientes dessas mudanças (BASTOS, 2018).
} 
fraternidade é tida como um dos pilares para que a dignidade humana seja alcançada (WOLKER, 2013).

Não são somente discussões em sentidos verticais e horizontais que devem ser travadas quando o assunto são direitos, mas também cabe colocar que a ideia da solidariedade deve se fazer presente nas relações subjetivas e aqui, cabe encaixar não só as oriundas de formações familiares como também de todos aqueles que de alguma forma colaboram para a efetivação e concretização de garantias fundamentais de crianças e adolescentes.

\section{CONCLUSÃO}

O caminho da sociedade pós-moderna é algo sem volta, avanços possibilitam o surgimento de outros progressos e assim por diante. Sem dúvida nenhuma, dizer que o corpo social hodierno é fruto de uma globalização e investimentos no setor de informação é reconhecer que a vida em sociedade, hoje, necessita sim do auxílio de aparelhos e instrumentos que venham a acrescentar em uma maior e melhor qualidade de vida.

Entretanto, todo avanço implica no superar de algo pretérito, talvez a liquidez das relações atuais seja em decorrência da superada solidez entre laços modernos. A tecnologia dentro das famílias não pode ser o combustível para essa constatação, pelo contrário deve haver um trabalho de (re) conhecimento dos pais em relação ao uso dessa inovações e como tais afetam na vivência e convivência com seus filhos, como afeta na formação enquanto sujeito de direitos e como pode corroborar para formação de pessoas carentes de modelos e orientação.

Judicializar a distração da parentalidade é algo sério, é reavaliar o dever jurídico, moral, social na contribuição da feitura de um cidadão, é tirar o foco de quem deve ter a consciência que em alguns momentos deixar o telefone celular de lado e valorizar situações e momentos com seus filhos é algo que não retrocede. Talvez a ingerência de meios alternativos para a resolução de conflitos seja algo mais viável, proporcionar que pais e filhos conversem a respeito ou ainda oferecer soluções que vão nutrir o sentimento e conciliar o dever parental, seja algo mais razoável a ser feito.

Falar de afeto e cuidado na sociedade tecnológica é difícil, a forte individualização do homem tende a torná-lo alguém autossuficiente em suas relações, desafios, trabalhos, convívios e dilemas. Estar em companhia passou a ser algo relativo e a ideia de compartilhar parece implicar em uma via de mão única. Todavia, por mais que o sujeito pós-moderno se apresente 
enquanto suficientemente preparado para viver em sociedade, falta-lhe a sensibilidade necessária para tratar consigo e com os outros de forma minimamente digna. Conceitos devem ser revistos, atitudes devem ser questionadas e indagações devem ser humanizadas, afinal de contas o afeto em uma sociedade tecnológica deve simbolizar muito mais do que a solidez mais genuína do ser humano, e sim demonstrar em tempos pós-globalizados a conectividade que realmente importa. 


\section{REFERÊNCIAS BIBLIOGÁFICAS}

ALMEIDA, Elenara Chaves Edler de. O Portal de Periódicos da Capes: estudo sobre a sua evolução e utilizaçãa. Dissertação (Mestrado) - Centro de Desenvolvimento Sustentável- CDS, Universidade de Brasília, UnB, 2006. Disponível em: <http://repositorio.unb.br/bitstream/10482/2542/1/2006_Elenara\%20Chaves\%20Edler\%20de $\% 20$ Almeida.pdf $>$. Acesso em 15 de fevereiro de 2019.

BASTOS, Ísis. B. A.. A tecnologia como paradigma das relações familiares no século XXI: aproximações com a mediação e suas bases sociofilosóficas. In: MARQUES, Andréia Loth e CASTRO, Fernando Guilhon de. (Org.). Mediação: cenários e casos. 1. ed. Rio de Janeiro: Multifoco, 2018. p. 293-309.

; SOARES, Flaviana Rampazoo. Abandono de Cuidado: conscientizar e responsabilizar. As famílias e os desafios da contemporaneidade. Organizadores: Conrado Paulino da Rosa, Liane Maria Busnello Thomé. Autores: Ana Carolina da Costa e Fonseca... [et al.]. Porto Alegre: IBDFAM/RS, 2015.

BECK, Ulrich. Sociedade de Risco Mundial-em busca da segurança perdida. Leya, 2018.

BECKER, Daniel. Parentalidade Distraída. Entrevista cedida à Letícia Prazeres Falcão em 26 de dezembro de 2018 via telefone para o presente trabalho.

CARVALHO, Luzia Alves de. A condição Humana em tempo de globalização: a busca de sentido da vida. In: Revista Visões, 4 ed., v. 1, n. 2, jan/jun 2008. Disponível em: <http://www.fsma.edu.br/visoes/ed04/4ed_A_Condicao_Humana_Em_Tempo_De_Globaliza cao_Luzia_Alves.pdf $>$. Acesso em: 15 de fevereiro de 2019.

DE MORAES, Dênis. Sociedade midiatizada. Mauad Editora, 2018.

DIAS, Maria Berenice. A ética do afeto. Revista Jus Navigandi, ISSN 1518-4862, Teresina, ano 10, n. 668, 4 maio 2005. Disponível em: https://jus.com.br/artigos/6668. Acesso em: 10 de fevereiro de 2019.

GIDDENS, Anthony. Sociologia. 6ª Edição. Lisboa: Fundação Calouste Gulbenkian, 2001.

GIL, Antonio Carlos. Métodos e Técnicas de Pesquisa Social. São Paulo: Atlas, 1999

LIPOVETSKY, Gilles. Os tempos Hipermodernos. Trad. Mário Vilela. São Paulo: Editora Barcarolla, 2004.

LÔBO, Paulo. Direito Civil - Família. $2^{\text {a }}$ Ed. São Paulo: Saraiva, 2009.

LOMEU, Leandro Soares. Afeto, abandono, responsabilidade e limite: diálogos sobre ponderação. Revista IOB de Direito de Família, Porto Alegre: Síntese, v. 11, p. 105-117, 
2010. Disponível em: http://www.ibdfam.org.br/_img/congressos/anais/222.pdf. Acesso em 10 de fevereiro de 2019.

MCDANIEL, Brandon T.; RADESKY, Jenny S. Technoference: Parent distraction with technology and associations with child behavior problems. Child development, v. 89, n. 1, p. 100-109, 2018. Disponível em: https://onlinelibrary.wiley.com/doi/full/10.1111/cdev.12822. Acesso em 10 de fevereiro de 2019.

SAMPAIO, Kelly Cristine Baião. Reflexões acerca da incidência dos princípios da liberdade individual e da solidariedade social nas relações familiares. Revista Ética e Filosofia Política, v. 2, n. 2009.2 Disponivel em: http://www.ufjf.br/eticaefilosofia/edicoes/anteriores/numeroxi-volume-i-jundez-2009/. Acesso em 15 de fevereiro de 2019.

SANTIAGO, Rafaela Prado. A interação do usuário com a biblioteca por meio da web 2.0: estudo de caso com bibliotecas do Distrito Federal. 2012. Monografia (Bacharel em Biblioteconomia) - Faculdade de Ciência da Informação, Universidade de Brasília (UnB), Brasília, 2012. Disponível em: <http://bdm.unb.br/bitstream/10483/3692/1/2012_RafaelaPradoSantiago.pdf>. Acesso em: 15 fevereiro de 2019.

TARTUCE, Flávio. Danos Morais por Abandono Moral. Revista Brasileira de Direito das Famílias e Sucessões. Porto Alegre, Magíster; Belo Horizonte: IBDFAM, ano X, n. 7, p.100115, dez./jan. 2009.

THOMAZINI, Magnus Guerreiro; GOULART, Elias Estevão. RELAÇÕES FAMILIARES: A INFLUÊNCIA DO VIRTUAL. Revista Interações. Vol.14. $n^{\circ}$ 47. 2018. Tecnologias de Informação e Comunicação-Perspectivas e Desafios. Disponível em: https://revistas.rcaap.pt/interaccoes/article/view/14182. Acesso em 15 de fevereiro de 2019.

WOLKMER, Antonio Carlos. Introdução aos fundamentos de uma teoria geral dos "novos" direitos. In: Revista Jurídica, v. 2, n. 31, 2013. p. 121-148. Disponível em: http://revista.unicuritiba.edu.br/index.php/RevJur/article/view/593/454. Acesso em 06 de março de 2019. 